\title{
The Salittu Formation in southwestern Finland, part I: Structure, age and stratigraphy
}

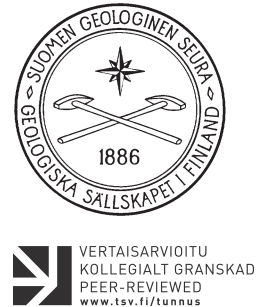

\section{Abstract}

Because of the relatively low metamorphic grade, low strain and well-preserved early structures in volcanic and volcaniclastic rocks, the Orijärvi triangle (in the center of the larger Orijärvi area) is one of the few locations in the Svecofennian orogen of southern Finland where lithostratigraphy has been determined. The geochemistry of the picriticbasaltic metavolcanic rocks of the Salittu Formation, located in the northeastern part of the Orijärvi area, has been characterized but otherwise the bedrock and structures have been barely touched. After remapping we give an interpretation of structural evolution, provide new age data to constrain duration of volcanism at Salittu, and refine the stratigraphy in the Orijärvi area.

The original stratigraphy is visible at Salittu: metabasalt overlies migmatitic gneisses, and metapicrite is on top. The rocks were folded during early Svecofennian $D_{1}-D_{2}$ deformations, and the large synformal structures developed as $D_{2}-D_{5}$ interference structures formed during late Svecofennian $\mathrm{D}_{5}$ deformation. The structural pattern at Salittu is much the same as in the Orijärvi triangle.

The new age data, combined with earlier published data, constrains the Salittu volcanism at ca. $1875 \mathrm{Ma}$. The stratigraphy in the Orijärvi area consists of the early (1.90-1.89 Ga) volcanic Orijärvi Formation, overlain by the sedimentary Vetio Formation, the volcanic Kisko Formation, the volcanic-sedimentary Ahdisto Formation, the volcanic Toija Formation, and on top the Salittu Formation, all emplaced at 1.88-1.87 Ga. We propose a model in which the Orijärvi Formation represents magmatism at the margin of a microcontinent, and the overlying package represents sedimentation and magmatism above a subduction zone during an initial stage of microcontinental accretion. $D_{1}$ deformation occurred in an advanced stage of accretion, after emplacement of the volcanic rocks of the Salittu Formation.

Keywords: metavolcanic rocks, gabbros, volcanism, structural geology, stratigraphy, $\mathrm{U}-\mathrm{Pb}$, zircon, Paleoproterozoic, Orijärvi, Salittu, Finland

*Corresponding author (e-mail: mikko.nironen@gtk.fi) 


\section{Introduction}

The Svecofennian bedrock in the Uusimaa belt in southernmost Finland is characterized by rather high strain and high grade metamorphism, reaching granulite grade e.g. in the West Uusimaa Complex (Fig. 1; Parras, 1958). There are also areas of lower amphibolite facies assemblages such as the Orijärvi area. Because Orijärvi is an old mine area, early geological studies were focused on ore mineralogy and alteration of the rocks around the mines. Eskola (1914) presented petrology of rocks in the larger Orijärvi area and described also an ultramafic rock at Salittu which he considered a plutonic peridotite.

The structural interpretation of the western Uusimaa belt by Tuominen (1957) included two shear zones, later called the Kisko and Jyly shear zones (Fig. 1). In the 1970's and 1980's the research projects by the Free University of Amsterdam led to a series of papers on metamorphism (Schreurs, 1984; Schreurs, 1985; Schreurs and Westra, 1986; Blom, 1988) and structures (Bleeker and Westra, 1987; Ploegsma and Westra, 1990; Ploegsma, 1991) in the central Uusimaa belt. Ploegsma and Westra (1990) called the triangular area bordered by Kisko and Jyly shear zones the Orijärvi triangle. They considered it a low-strain area that preserved early (D1) folds and was protected from regional deformation during later deformation events (D2, D3). More recently Skyttä et al. (2006) and Pajunen et al. (2008) described profoundly the structures in the Orijärvi triangle and presented slightly different interpretations of structural evolution. The rocks at Salittu, to the northeast of the Orijärvi triangle were studied as well: Schreurs et al. (1986) were the first to consider the ultramafic rocks at Salittu to be of volcanic origin and they presented basic geochemistry of these rocks. Since the 1980's tentative interpretations of structures at Salittu have been given by Skyttä and Mänttäri (2008) and Pajunen et al. (2008).

Because of the relatively low metamorphic grade, low strain and well-preserved early structures in volcanic and volcaniclastic rocks, the Orijärvi area is one of the few regions in southern Svecofennia of Finland where reliable structural evolution and lithostratigraphy can be determined. Väisänen and Mänttäri (2002) presented the stratigraphy of the supracrustal rocks in the Orijärvi area (including Salittu), with four formations: Orijärvi (oldest), Kisko, Toija, and Salittu (youngest), with an age span from 1.90 Ga to $1.88 \mathrm{Ga}$. The Salittu Formation (SFm) differs from the other ones by the characteristic metapicrites (metapicrite occurs in the Toija Formation as well). The geochemistry of the picritic-basaltic volcanism at Salittu is studied in a companion paper (Nironen, submitted).

Based on remapping of the area where the rocks of the SFm occur we give an interpretation of structural evolution. In addition, we provide additional age data to earlier published ages to constrain the duration of volcanism at Salittu, provide and interpretation of stratigraphy at Salittu, and refine the stratigraphy in the Orijärvi area.

\section{Geological setting}

The Paleoproterozoic tectonic evolution in Fennoscandia, including the Svecofennian orogeny, has been modeled basically in two ways. In the first semi-continuous, protracted accretion of island arcs to the Archean craton led to southwestward growth of the orogenic belt (Gorbatchev and Bogdanova 1993); in a refinement of this model continuous long-lived subduction occurred with repeated retreating and advancing stages (Hermansson et al., 2008; Stephens and Andersson, 2015). The second model involves accretion of microcontinents (Nironen, 1997), and the orogeny consisted of separate orogenic stages, including microcontinent accretion (1.92-1.87 Ga), continental extension (1.86-1.84 Ga), continental collision (1.84-1.79 $\mathrm{Ga})$, and finally orogenic collapse and stabilization (1.79-1.77 Ga: Lahtinen et al., 2005). According to the second model the Svecofennian orogen in southern Finland may be divided into Central Svecofennia with a microcontinent in the core, and Southern Svecofennia with another microcontinent 
Figure 1.

Geological

map of the

Orijärvi area,

modified from

Salli (1955) and

Väisänen and

Mänttäri (2002).

OFm = Orijärvi

Formation,

$\mathrm{KFm}=$ Kisko

Formation,

TFm = Toija

Formation,

SFm = Salittu

Formation. Inset

shows location

of the Orijärvi

area (thick black

line) within the

Uusimaa belt

(UB). WUC =

West Uusimaa

Complex.

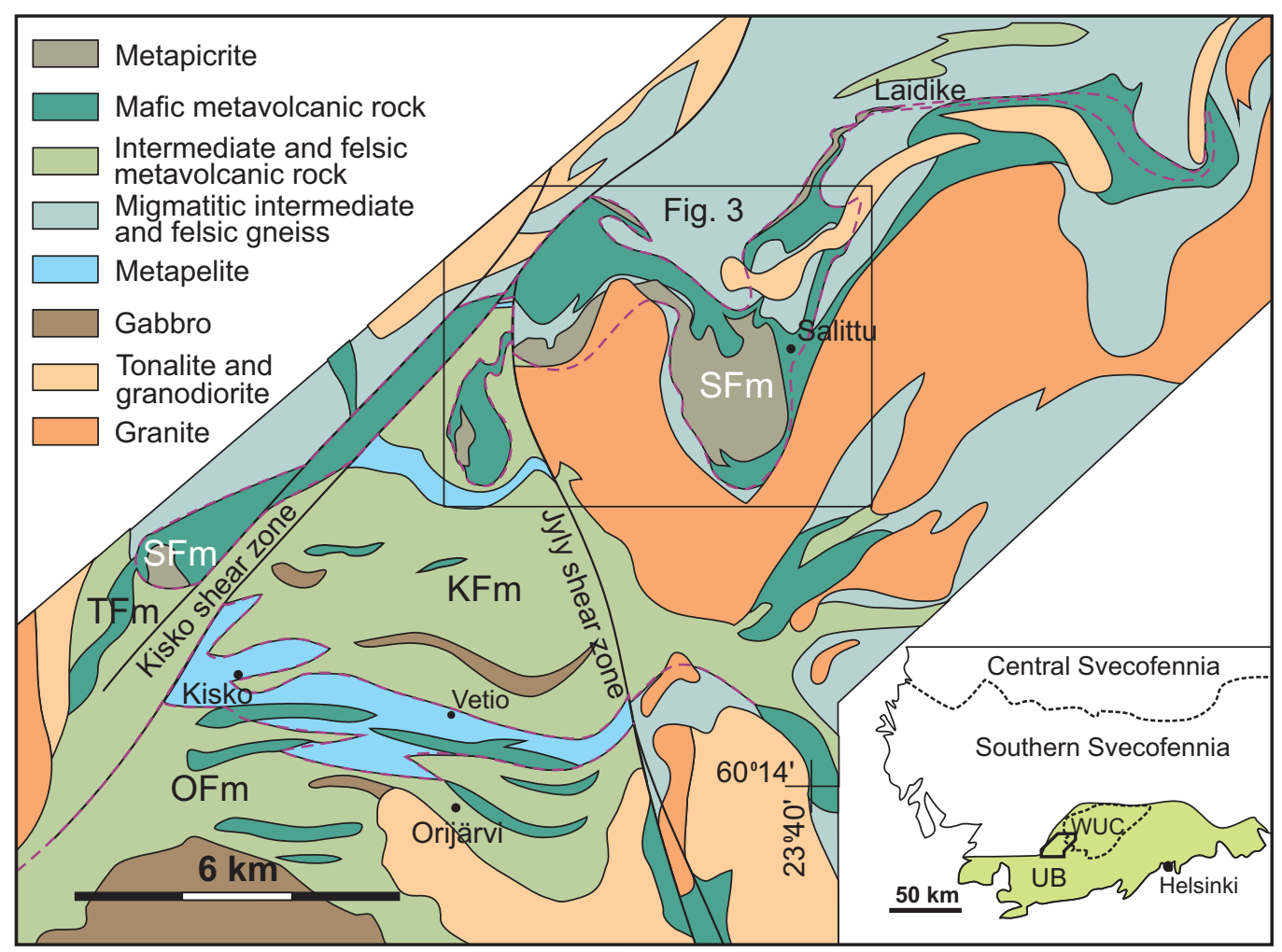

Figure 2.

Aeromagnetic map of the

Orijärvi area

(GTK database).

Majorshear

zones (solid line)

and extent of

the rocks of the

Salittu Formation (broken line) are shown.

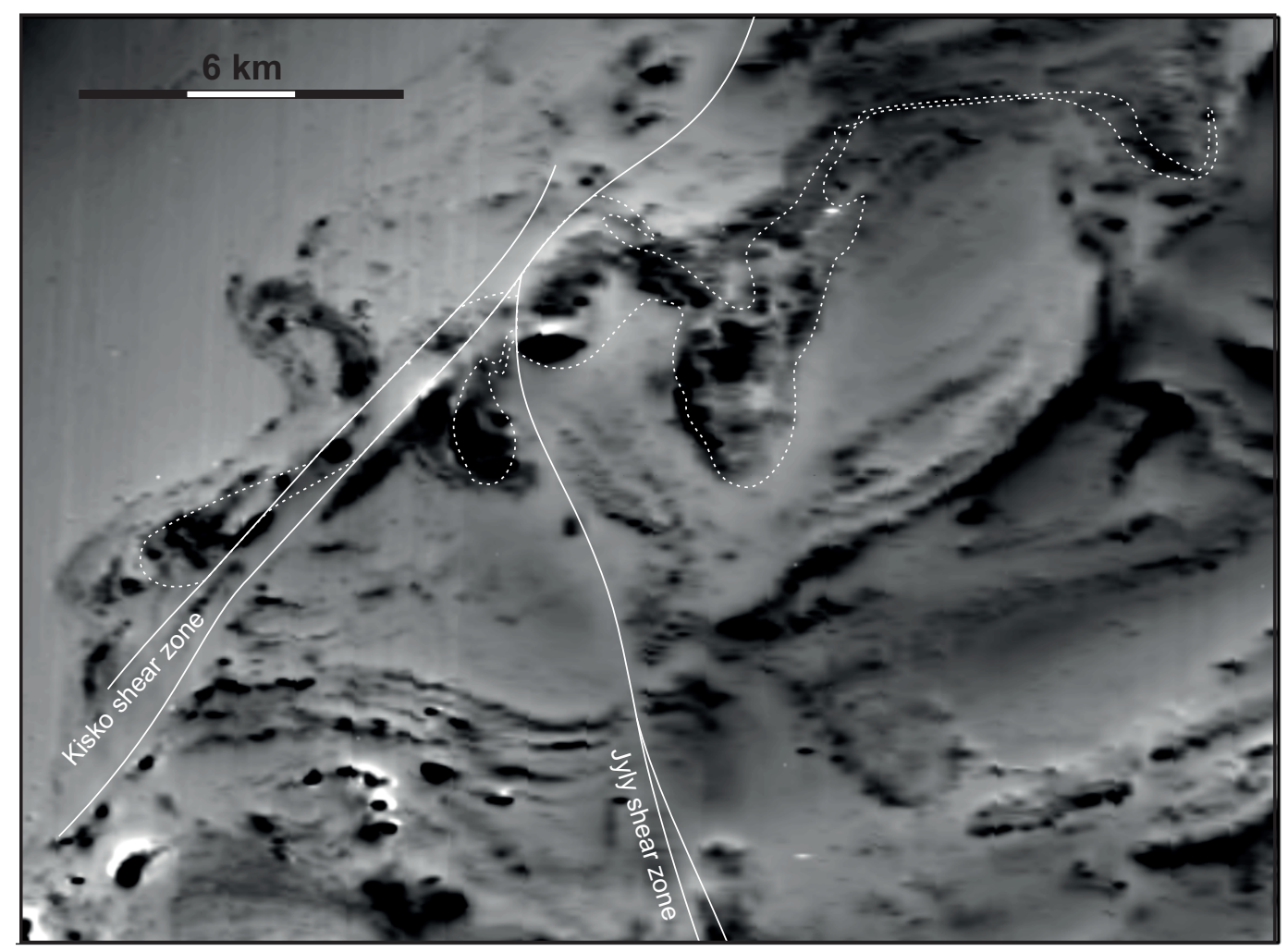


(Fig. 1, inset). The difference between these accretionary units is that whereas both display structural and metamorphic evolution attributed to microcontinental accretion, in Southern Svecofennia this evolution is overprinted by another one, attributed to continental collision.

Magmatism and metamorphism during the Svecofennian orogeny in Southern Svecofennia may be divided into the early Svecofennian (1.90$1.87 \mathrm{Ga}$ ) and the late Svecofennian (1.84-1.79 $\mathrm{Ga})$ periods. The early Svecofennian period was followed by an intra-orogenic phase of minor magmatism (Bergman et al., 2008; Väisänen et al., 2012). The late Svecofennian granitic magmatism and associated high-temperature, low-pressure type metamorphism overprinted the early Svecofennian magmatism, metamorphism and deformation in a wide belt called the Late Svecofennian GraniteMigmatite zone (Ehlers et al., 1993) that covers southernmost Finland.

The supracrustal rocks in the Uusimaa belt are mainly metavolcanic and volcanic-derived metasedimentary rocks, with epiclastic schists and gneisses as minor constituents. They were metamorphosed during the early Svecofennian period at amphibolite facies conditions (Pajunen et al., 2008). The lower amphibolite facies rocks in the Orijärvi triangle include andalusite-cordierite schists; this area was largely preserved from the late Svecofennian deformation and metamorphism. Skyttä et al. (2006) explained the preservation of the early Svecofennian structures by strain partitioning into high-strain zones (the Jyly and Kisko shear zones; Figs. 1 and 2).

The metamorphic grade increases from the Orijärvi triangle, and most of the rocks at Salittu are migmatitic (Fig. 3). Peak regional metamorphic pressure of 3 kbar (Latvalahti, 1979) and temperature of $600^{\circ} \mathrm{C}$ (Schumacher and Czank, 1987) have been estimated for the Orijärvi triangle. Schreurs and Westra (1986) suggested an increase in peak metamorphic temperature from $550-650^{\circ} \mathrm{C}$ in the Orijärvi triangle to $700-825^{\circ} \mathrm{C}$ in the West Uusimaa Complex at 3-5 kbar pressure. Mouri et al. (2005) estimated $750-800^{\circ} \mathrm{C}$ and $4-5 \mathrm{kbar}$ conditions in the West Uusimaa Complex during peak of the late Svecofennian metamorphism (1.83-1.81 Ga). According to Schreurs (1985), the increase in metamorphic grade and development of the West Uusimaa Complex was a thermal, virtually isobaric event, and therefore Schreurs and Westra (1986) suggested that the whole region, including the Orijärvi area, represents one crustal level. However, Skyttä et al. (2006) noted an abrupt change in metamorphic grade across the Jyly shear zone and interpreted that the Jyly and Kisko shear zones acted as block margins during the late Svecofennian period, with reverse (east-side-up) dip-slip movement in the Jyly shear zone.

\section{Rock types}

The SFm consists of pictitic and basaltic metavolcanic rocks. The extent of the SFm in the Orijärvi area is about $20 \mathrm{~km}$ (Fig. 1), and considering the metapicrite occurrences farther east the total length exceeds $30 \mathrm{~km}$. In the aeromagnetic map the metavolcanic rocks of the SFm show up as positive anomalies (Fig. 2).

The metabasalt is generally compositionally banded (Fig. 4a) but breccia structures are rather common, and pillow structure occurs locally. The metapicrite varies from homogeneous to fragmental type that probably represents volcanic breccia. Inclusions of metabasalt in the metapicrite (Fig. 4b) show that picrite erupted after basalt and dragged fragments of the basalt into the lava. The boundary of the metapicrite and metabasalt is usually tectonized but sharp where a primary contact can be found (Fig. 4c).

In addition to the metavolcanic rocks, the supracrustal sequence at Salittu consists of felsicintermediate gneisses and mafic schists (Fig. 3). The gneisses are migmatitic, with leucosome veins usually parallel to compositional layering. Quartz-feldspar gneiss is light-colored and faintly layered (Fig. 4d). As the gneiss does not contain aluminosilicate porphyroblasts, it is probably volcaniclastic in origin. Quartz-feldspar gneiss 


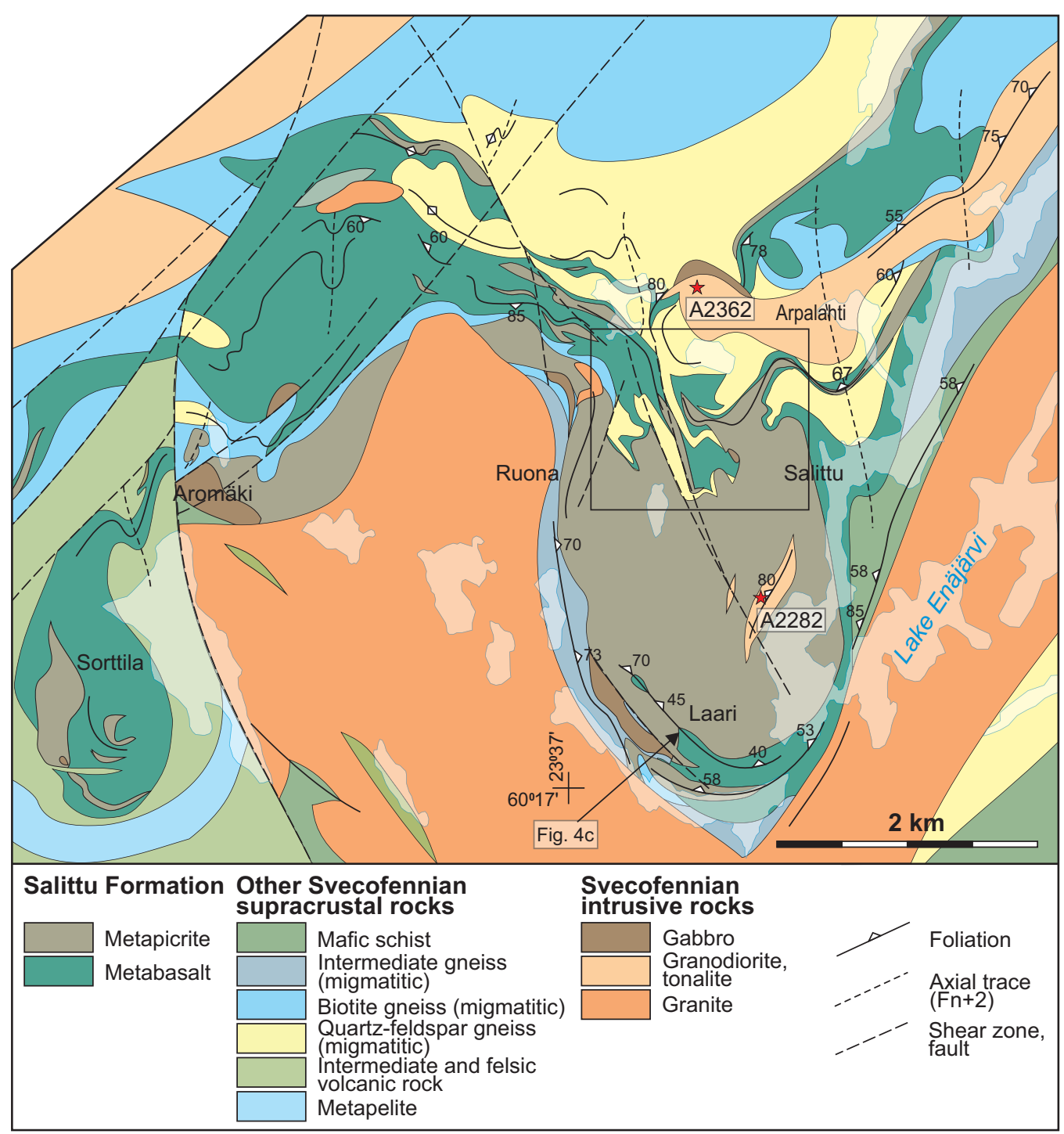

Figure 3. Geological map of the Salittu area, modified from Salli (1955), Schipper (1981), and Väisänen and Mänttäri (2002). Location of Figure 6 is shown by rectangle. Sample sites for age dating are shown by red stars. The foliation form lines show orientation of the prominent foliation $\left(\mathrm{S}_{\mathrm{n}}\right.$ or $\mathrm{S}_{\mathrm{n}}-\mathrm{S}_{\mathrm{n}+1}$ in supracrustal rocks).

grades into cordierite-bearing biotite gneiss, indicating an increasing proportion of weathered material in the protolith. There are also gneisses of intermediate composition with some hornblende as well as diopside- and amphibole-bearing mafic schists; these rocks are likely of volcanic or volcanic-sedimentary origin. Garnet-bearing biotite paragneiss occurs scatteredly and represents epiclastic sedimentary rocks that are scarce at Salittu.
At Sorttila, within the Orijärvi triangle area (Fig. 5), the metavolcanic rocks are much similar to the metavolcanic rocks at Salittu. The rocks surrounding the metavolcanic rocks are intermediate, faintly layered schists, interpreted to have a volcanic or volcanic-sedimentary origin (tuffs or redeposited tuffs). Farther south the schists contain andalusite porphyroblasts indicating sedimentary origin. 

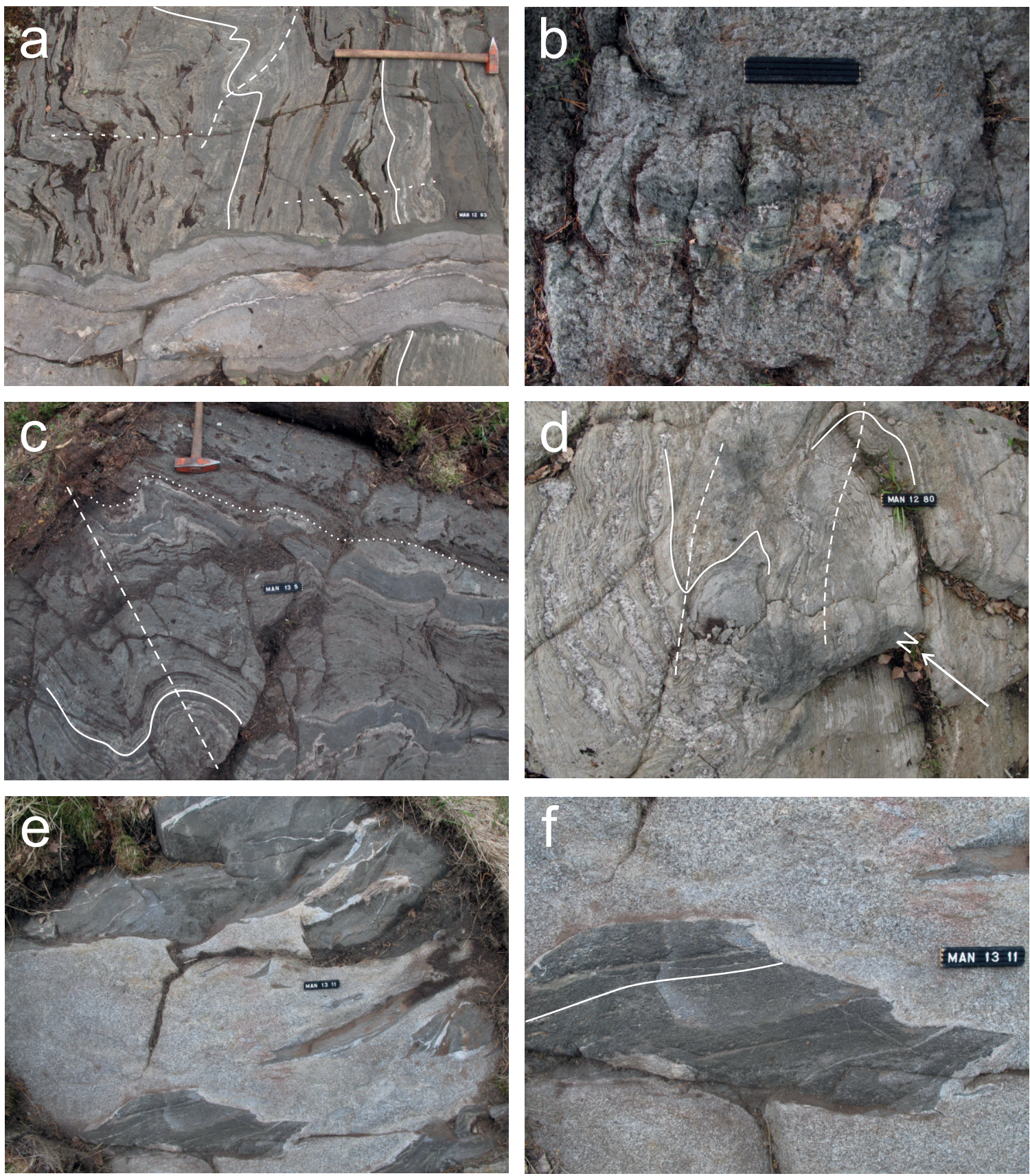

Figure 4. Outcrop photographs from the Salittu area. a. Foliation in metabasalt ( $S_{n}$, solid white line), parallel to compositional layering, is deformed by tight, sinistral $F_{n+1}$ folding which is folded by open folding $\left(F_{n+2}\right)$. $F_{n+1}$ and $F_{n+2}$ axial traces are shown by broken and dotted white lines, respectively. A composite dike crosscuts all structures. Shaft of hammer (length $60 \mathrm{~cm}$ ) points to north. b. Inclusion of metabasalt in metapicrite. Length of code bar $12 \mathrm{~cm}$. c. Primary contact (dotted white line) between metabasalt of fragmental type (upper part of figure) and metapicrite. Dark alteration bands occur at the base of the metapicrite. Sinistral folding $\left(F_{n+1}\right)$ of banding $\left(S_{n}\right)$ is visible. Shaft of hammer points to north. d. Quartz-feldspar gneiss. Foliation parallel to compositional layering $\left(\mathrm{S}_{n}\right)$ and leucosome veins are tightly folded ( $F_{n+1}$; axial trace shown). e. Intrusive contact of Arpalahti tonalite with metabasalt. f. Detail of the intrusive contact. Note how the almost undeformed tonalite crosscuts foliation $\left(\mathrm{S}_{\mathrm{n}}\right)$ in the metabasalt. 
Gabbroic bodies occur within and adjacent to the metavolcanic rocks. The largest body within the metavolcanic rocks at Aromäki (Fig. 3) is mediumgrained and unfoliated. Gradational contacts to metapicrite and similar geochemistry (Nironen, submitted) suggest that the Aromäki gabbro is synvolcanic with respect to metapicrite. In contrast, the body at Laari consists of fine- to mediumgrained, foliated intrusive rock that varies in composition from gabbro to diorite and is crosscut by the metapicrite.

An elongate body in the northern part of the Salittu area (Fig. 3), here named as the Arpalahti tonalite, crosscuts the metabasalt of the SFm (Figs. $4 \mathrm{e}, 4 \mathrm{f})$. The tonalite is homogeneous, mediumgrained, generally foliated but less foliated at the ends of the elongate body. A sample (A2362) was taken from the tonalite for dating. Another sample (A2282) was taken from a foliated, medium-grained granodiorite, here named as the Laari granodiorite, occurring within the metapicrite (Fig. 3).

A large, elongate granite body occupies the southern part of the study area and crosscuts all the supracrustal rocks (Fig. 1). It is medium- to coarsegrained and almost unfoliated except for a few shear zones. In addition, small granite bodies crosscut the ductile structures in the metavolcanic rocks but some of these granites are deformed by faults (Fig. 6).

\section{Structure}

The Salittu Formation trends approximately ENEWSW (Fig. 1). A small area in the center of the Salittu area, with good outcrop density and easily distinguishable rock types, was studied in detail to understand the structure (Fig. 6). The quartzfeldspar gneiss and biotite gneiss exhibit a weak compositional layering, and leucosome veins are (sub)parallel to the layering. Generally the amount of mica is small in the gneisses but a schistosity $\left(\mathrm{S}_{\mathrm{n}}\right)$ can be seen in more mica-bearing layers (mainly in the biotite gneiss). Compositional layering in the metabasalt has the same orientation as layering in

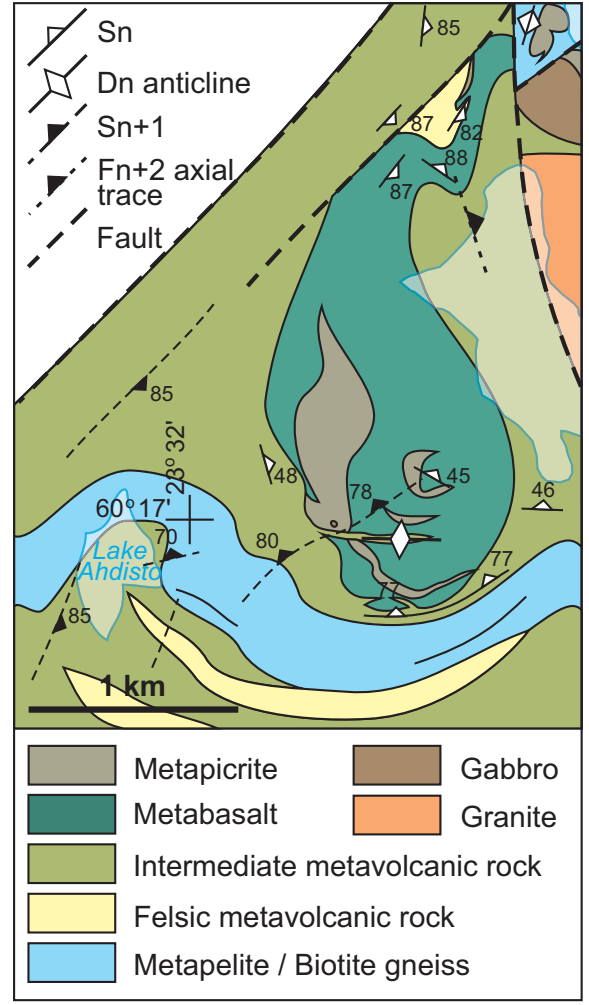

Figure 5. Geological map of the Sorttila area within the Orijärvi triangle, based on observations of this study and GTK bedrock database.

the adjacent quartz-feldspar gneiss, and is therefore considered to define $\mathrm{D}_{\mathrm{n}}$ foliation.

$S_{n}$ foliation and leucosome veins in the gneisses are tightly to isoclinally folded $\left(\mathrm{F}_{\mathrm{n}+1}\right)$. A faint, steeply dipping to vertical $S_{n+1}$ foliation can be identified in the axial plane in the mica-bearing layers (Fig. 4d). The $\mathrm{F}_{\mathrm{n}+1}$ fold axis plunges vary from subhorizontal to steep, and a mineral lineation $\left(\mathrm{L}^{\mathrm{n}}{ }_{\mathrm{n}+1}\right)$ is parallel to the fold axis. $\mathrm{F}_{\mathrm{n}+1}$ folding is visible also in the metabasalt (Fig. 4a).

The $\mathrm{F}_{\mathrm{n}+1}$ folding is deformed by upright, open to tight folding $\left(\mathrm{F}_{\mathrm{n}+2}\right)$ with NNW-SSE to NNESSW striking subvertical axial planes (Figs. $4 \mathrm{a}$ and $6)$. Based on interpretation of the structures in the area of Figure 6, the synformal structure at Laari results from interference of two, almost orthogonal foldings $\mathrm{F}_{\mathrm{n}+1}$ and $\mathrm{F}_{\mathrm{n}+2}$. 


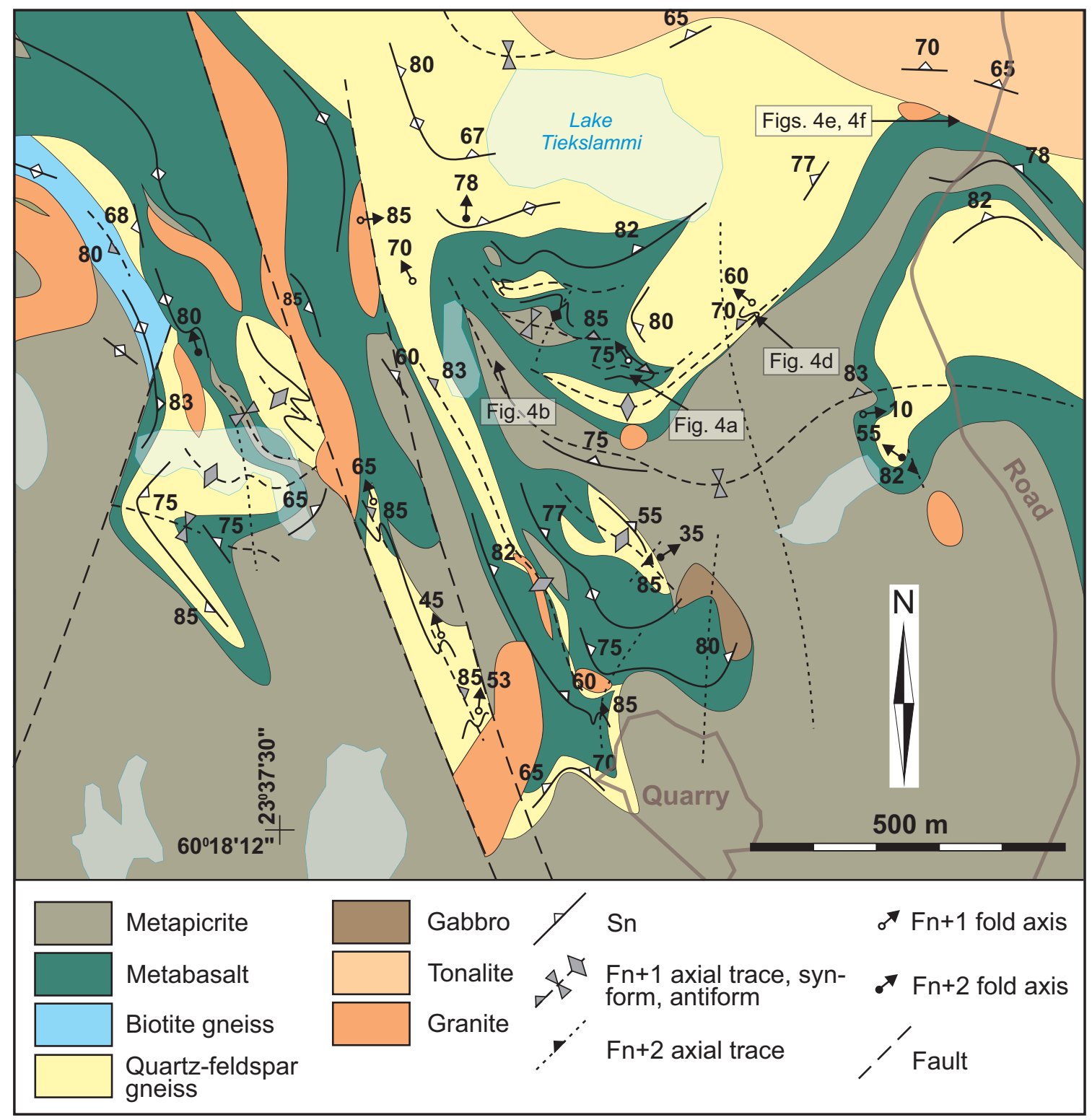

Figure 6. Structural interpretation of the Ruona-Arpalahti area.

At Sorttila, the structural sequence is correlative to that at Salittu. The intermediate metavolcanic schist displays a rather weak $S_{n}$ foliation, and compositional layering in the metabasalt is parallel to $S_{n}$ (Fig. 5). Rather open $F_{n+1}$ folding deforms $S_{n}$ in the schist and compositional layering in the metabasalt, with development of a schistosity in the axial plane. In the southern part of the area the intermediate schist crops out as an E-W directed narrow lense within the metabasalt. Since $S_{n+1}$ foliation is visible within this lense, the structure is interpreted as a $D_{n}$ anticline. In the northeastern part of Sorttila, $S_{n}$ compositional layering in the metabasalt is tightly folded, with axial plane in NNE-SSW direction. This folding is interpreted as $\mathrm{F}_{\mathrm{n}+2}$.

The sharply crosscutting contact of the Arpalahti tonalite to the foliated $\left(S_{n}\right)$ metabasalt 
(Fig. 4f) indicates that the tonalite intruded during a late stage or after $\mathrm{D}_{\mathrm{n}}$. The tonalite is foliated (Figs. 2 and 6) but it is difficult to assess whether this foliation correlates with $S_{n}$ or $S_{n+1}$ in the supracrustal rocks because the two are parallel in many places. The form of the tonalite body suggests that it was deformed during $\mathrm{D}_{\mathrm{n}+2}$ (Fig. 1).

An unfoliated composite (mafic) dike was found to sharply crosscut the foliation and folding in the metabasalt (Fig. 4a). The subvertical dike is oriented parallel to $\mathrm{F}_{\mathrm{n}+2}$ fold axial plane, suggesting emplacement during $\mathrm{D}_{\mathrm{n}+2}$.

Numerous faults at Salittu appear as discontinuities in lithology (Fig. 6) and as linear depressions in topography. They are exposed on few outcrops where they occur as narrow mylonitic zones. Larger shear zones were interpreted on the basis of the aeromagnetic data (Fig. 2) and discontinuities in lithology.

To the north of Salittu, at Laidike (Fig. 1), there is tight folding with E-W axial trace. The relative age of this folding is open: it may be $\mathrm{F}_{\mathrm{n}+1}$ folding, or it may be the youngest deformation in the area.

\section{U-Pb zircon dating}

\subsection{Analytical methods}

Zircon for LA-MC-ICPMS (Laser Ablation Multi-collector Inductively Coupled Plasma Mass Spectrometry) U-Pb dating were selected by handpicking after heavy liquid and Frantz magnetic separation. The chosen grains were mounted in epoxy resin and sectioned approximately in half and polished. Back-scattered electron images (BSE) and cathodo luminescence (CL) images were taken using SEM (Scanning Electron Microscope) to target the spot analysis sites on mineral grains.

$\mathrm{U}-\mathrm{Pb}$ dating analyses were performed using a $\mathrm{Nu}$ Plasma HR multicollector ICPMS at the Geological Survey of Finland in Espoo using a technique very similar to Rosa et al (2009) except that Analyte G2 193 nm laser laser microprobe was used. The analyses were made in static ablation mode with beam di- ameter of $20 \mu \mathrm{m}$, pulse frequency of $10 \mathrm{~Hz}$, and beam energy density of $2.07 \mathrm{~J} / \mathrm{cm}^{2}$. A single $\mathrm{U}-\mathrm{Pb}$ measurement included 30 s of on-mass background measurement, followed by $60 \mathrm{~s}$ of ablation with a stationary beam. Masses 204, 206 and 207 were measured in secondary electron multipliers and 238 in the extra high mass Faraday collector. Ion counts were converted and reported as volts by the $\mathrm{Nu}$ Plasma timeresolved analysis software. ${ }^{235} \mathrm{U}$ was calculated from the signal at mass 238 using a natural $238 \mathrm{U} / 235 \mathrm{U}=137.88$. Mass

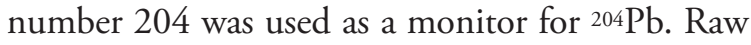
data were corrected for background, laser induced elemental fractionation, mass discrimination, and drift in ion counter gains and reduced to $\mathrm{U}-\mathrm{Pb}$ isotope ratios by calibration to concordant reference zircon of known age, using protocols adapted from Andersen et al. (2004) and Jackson et al. (2004). Standard zircon GJ-01 (609 $\pm 1 \mathrm{Ma}$; Belousova et al., 2006) and an in-house standard zircon A1772 $(2711 \pm 3 \mathrm{Ma}$ /TIMS; $2712 \pm 1 \mathrm{Ma} /$ SIMS; Huhma et al., 2012) were used for calibration. In addition, A382 (1877 \pm 2 Ma; Huhma et al., 2012) was measured as a quality control sample to check the calibration (1882 $\pm 6 \mathrm{Ma}$; MSWD of concordance $=4.8 ;$ Mean ${ }^{207} \mathrm{~Pb} /{ }^{206} \mathrm{~Pb}$ age $=1880 \pm 5 \mathrm{Ma}$; MSWD = 0.95; $\mathrm{n}=25 / 25$. MSWD = Mean Square Weighted Deviation). Age related common lead (Stacey and Kramers, 1975) correction was used when the analysis showed common lead contents above the detection limit. The calculations were done off-line, using an interactive spreadsheet program written in Microsoft Excel/ VBA by Tom Andersen (Rosa et al, 2009). To compensate for drift in instrument sensitivity and Faraday vs. electron multiplier gain during an analytical session, a correlation of signal vs. time was assumed for the reference zircons. A description of the algorithms used is provided in Rosa et al (2009).

The age calculations and plotting of the $\mathrm{U}-\mathrm{Pb}$ isotope data were performed using the Isoplot/ Ex 3 program (Ludwig, 2003). All the ages were calculated with $2 \sigma$ errors and without decay constant errors. Data-point error ellipses in the figures are at the $2 \sigma$ level. 
Table 1. LA-MC-ICPMS zircon U-Pb data, Laari granodiorite and Arpalahti tonalite.

\begin{tabular}{|c|c|c|c|c|c|c|c|c|c|c|c|c|c|c|c|c|c|c|}
\hline \multirow[b]{2}{*}{$\begin{array}{l}\text { Sample/ } \\
\text { spot \# }{ }^{4)}\end{array}$} & \multicolumn{6}{|l|}{ Ages } & \multicolumn{12}{|c|}{ Ratios } \\
\hline & ${ }^{206} \mathrm{~Pb}$ & $\pm \sigma$ & ${ }^{207} \mathrm{~Pb}$ & $\pm \sigma$ & ${ }^{206} \mathrm{~Pb}$ & $\pm \sigma$ & ${ }^{207} \mathrm{~Pb}$ & $\pm \sigma$ & ${ }^{207} \mathrm{~Pb}$ & $\pm \sigma$ & ${ }^{206} \mathrm{~Pb}$ & $\pm \sigma$ & $\rho^{1)}$ & $\begin{array}{l}\text { Disc. } \\
\%^{2)}\end{array}$ & $\left.U\right|_{\mathrm{ppr}}$ & & $\begin{array}{l}{ }^{206} \mathrm{~Pb} /{ }^{204} \mathrm{~Pb} \\
\text { measured }\end{array}$ & $\begin{array}{l}f_{206} \\
\%^{3)}\end{array}$ \\
\hline \multicolumn{19}{|c|}{ A2282 Laari granodiorite, Salittu } \\
\hline A2282_01a & 1875 & 17 & 1897 & 30 & 1917 & 56 & 0,11467 & 00111 & 5,47436 & 0,19171 & 0,34626 & 0,01166 & 0,96 & 2,6 & 650 & 304 & $3,98 E+05$ & 0,00 \\
\hline 2282_02a & 1857 & 17 & 1937 & 31 & 2014 & 59 & 0,11354 & 0,00111 & 5,74021 & 0,2047 & 0,36666 & 0,01257 & 0,96 & 9,8 & 606 & 300 & $8,33 E+03$ & 0,20 \\
\hline 2282 03a & 1867 & 18 & 1882 & 33 & 1895 & 61 & 0,11416 & 0,00114 & 5,38019 & 0,20595 & 0,34182 & 0,01263 & 0,97 & 1,8 & 344 & 157 & $1,69 E+04$ & 0,10 \\
\hline 2282 04a & 1873 & 18 & 1886 & 29 & 1898 & 54 & 0,11459 & 0,00112 & 5,40776 & 0,18575 & 0,34228 & 0,01127 & 0,96 & 1,5 & 488 & 226 & $5,58 E+04$ & 0,00 \\
\hline $2282 \_05 a$ & 1848 & 17 & 1914 & 34 & 1976 & 65 & 0,11301 & 0,00114 & 5,58777 & 0,22153 & 0,35861 & 0,01375 & 0,97 & 8 & 772 & 375 & $3,96 \mathrm{E}+04$ & 0,10 \\
\hline $2282 \_06 a$ & 1878 & 17 & 1885 & 32 & 1891 & 59 & 0,1149 & 0,00117 & 5,40125 & 0,20304 & 0,34095 & 0,01234 & 0,96 & 0,8 & 446 & 203 & $2,76 E+04$ & 0,00 \\
\hline $2282-07 a$ & 1849 & 18 & 1908 & 34 & 1964 & 65 & 0,11303 & 0,00115 & & & & & 0,97 & 7,2 & 1011 & 478 & & 0,00 \\
\hline 2282 & 1862 & 18 & 1913 & 30 & 1960 & 57 & 0,11387 & & & & & & 0,96 & 6,1 & 519 & & & 00 \\
\hline $228209 a$ & 1852 & 17 & 1883 & 30 & 1911 & 55 & & & & & & & & & 762 & & & \\
\hline & 1843 & 17 & 1916 & 32 & 1985 & 60 & & & & & & & & & & & & \\
\hline & 1922 & 7 & 191 & 33 & 1910 & 62 & & & & & & & & & & & & \\
\hline & 1875 & 7 & 1888 & 33 & 1900 & 60 & & & & & & & & & & & & \\
\hline $32 \_13 a$ & 1862 & 18 & 1908 & 31 & 1950 & 58 & & & & & & & & & & & & \\
\hline $32 \_14 a$ & 1867 & 18 & 1895 & 30 & 1921 & 56 & 0,11417 & & & & & & & & 74 & & & \\
\hline 2 & 1866 & 18 & 1877 & 31 & 1886 & 58 & 0,11414 & & & & & & & & 64 & & & \\
\hline 2_16a & 1903 & 19 & 1896 & 37 & 1889 & 67 & 0,11646 & & & & & & 0,97 & & 47 & & +03 & \\
\hline & 1887 & 9 & 1909 & 34 & 1929 & 63 & & & & & & & & & 2 & & & \\
\hline & 1878 & 19 & 1851 & 37 & 1826 & 67 & & & & & & & 0,97 & & 73 & & & \\
\hline & 1900 & 18 & 1963 & 34 & 2023 & 65 & 163 & & & & & & & & 28 & & & \\
\hline & 1871 & 18 & 1859 & 32 & 1849 & 58 & 443 & & & & & & & & & & & \\
\hline \multicolumn{19}{|c|}{ A2362 Arpalahti tonalite, Salittu } \\
\hline A2362-01a & 1893 & 12 & 1904 & 32 & 1915 & 61 & & & & & & & & & 261 & & & 0,00 \\
\hline & 1898 & 13 & 1914 & 30 & 1929 & 56 & 0,11614 & & & & & & & & 301 & & & \\
\hline & 1870 & 13 & 1874 & 32 & 1878 & 60 & 0,11434 & & & & & & & & 165 & & & \\
\hline & 1916 & 12 & 1871 & 28 & 1831 & 50 & 0,11733 & 087 & & & & & 0,97 & & 177 & & & \\
\hline & 1867 & 12 & 1916 & 54 & 1961 & 106 & 0,11418 & & & & & & & & 120 & 6 & & \\
\hline & 1894 & 14 & 1891 & 33 & 1888 & 62 & 0,1159 & & & & & & & & & 58 & & \\
\hline & 1874 & 13 & 1892 & 29 & 1908 & 54 & 0,11464 & & & & & & 0,98 & & 407 & & & \\
\hline $2-05 a$ & 1898 & 13 & 1892 & 30 & 1887 & 55 & 0,11614 & & & & & & 0,97 & & & & & \\
\hline $2-05 b$ & 1890 & 14 & 1879 & 29 & 1869 & 54 & 0,11567 & & & & & & 0,97 & & 229 & 5 & & \\
\hline & 1877 & 14 & 1886 & 28 & 1894 & 52 & & & & & & & & & 362 & & & \\
\hline & 1911 & 20 & 1896 & 34 & 1882 & 63 & & & & & & & & & & & & \\
\hline & 1865 & 13 & 1859 & 46 & 1854 & & & & & & & & & & & & & \\
\hline & 1885 & 13 & 1 & 28 & 1875 & & & & & & & & & & & & & \\
\hline & 1854 & 5 & 1 & 30 & 2080 & 60 & & & & & & & & & & & & \\
\hline & 1882 & 1 & 1 & 58 & & & & & & & & & & & & & & \\
\hline & 1881 & 1 & & 57 & 1884 & 10 & & & & & & & & & & & & \\
\hline & 1878 & 1 & 1875 & 57 & 1872 & 108 & & & & & & & & & & & & \\
\hline & 1885 & 1 & 1916 & 58 & 1946 & 11 & & & & & & & & & 1 & & & \\
\hline & 1881 & 1 & 1892 & 57 & 1902 & 109 & & & & & & & & & & 9 & & \\
\hline & 1882 & 1 & 1885 & 56 & 1887 & 107 & & & & & & & & & & & & \\
\hline & 1888 & 11 & 1884 & 56 & 1881 & 107 & & & & & & & 1, & -0 & 99 & 0 & & 0 , \\
\hline & 1872 & 11 & 1900 & 57 & 1926 & 109 & & & & & & & 1, & & 217 & 8 & & 0,03 \\
\hline & 1883 & 1 & 188 & 56 & 1884 & 106 & & & & & & & & & & 9 & & 0 \\
\hline & 1888 & 11 & 1892 & 56 & 1896 & 107 & & & & & & & 1,00 & & 136 & 41 & & 0,01 \\
\hline & 1875 & 11 & 1897 & 55 & 1917 & 106 & 0,11472 & & & & & & 1,00 & & 351 & 108 & & 0,00 \\
\hline $2362-20 a$ & 1882 & 12 & 1858 & 53 & 1837 & 99 & 0,11514 & 00077 & 5,23398 & 0,32471 & 0,32968 & 0,02034 & 0,99 & $-2,8$ & 148 & 42 & +04 & 0,00 \\
\hline & 1869 & 12 & 1883 & 54 & 1896 & 102 & 0,1143 & 0,00076 & 5,39062 & 0,33708 & 0,34204 & 0,02127 & 0,99 & 1,7 & 272 & 30 & +04 & 0,03 \\
\hline $2362-21 a$ & 1876 & 11 & 1859 & 52 & 1845 & 97 & 0,11472 & 0,00076 & 5,24123 & 0,31922 & 33135 & 0,02006 & 0,99 & $-1,9$ & 134 & 38 & $1,55 \mathrm{E}+04$ & 0,00 \\
\hline & 1874 & 11 & 1883 & 52 & 1891 & 100 & 0,1146 & 0,00075 & & & & 0,02072 & 0,99 & 1,1 & 369 & 07 & $1,14 \mathrm{E}+05$ & 0,00 \\
\hline & 1869 & 11 & 192 & 55 & 1977 & 108 & & & & & & & 1,00 & & 33 & 132 & & 0, \\
\hline & 1834 & 11 & 182 & 52 & 1821 & 97 & 0,11213 & & & & & & 0,99 & -0 , & 1 & 18 & & 0,27 \\
\hline & 1877 & 11 & 1879 & 53 & 1882 & 100 & & 0,00075 & & & 0,338 & & 0,99 & 0 & 262 & 76 & & 0, \\
\hline & 1866 & 11 & 1880 & 53 & 1893 & 101 & & & & & & & & & & 47 & & 0, \\
\hline & 1850 & 12 & 1856 & 52 & 1861 & 97 & & & & & & & 0,99 & 0,7 & 17 & 50 & & 0,21 \\
\hline A2362-27a & 1884 & 11 & 1926 & 54 & 1966 & 106 & 0,11526 & 0,00075 & 5,66653 & 0,35491 & 0,35656 & 0,02221 & 1,00 & 5 & 148 & 45 & $2,08 E+04$ & 0,00 \\
\hline
\end{tabular}

All errors are in 1 sigma level. 1) Error correlation in conventional concordia space. 2) Age discordance at closest approach of 1 sigma error ellipse to concordia. 3) Percentage of common ${ }^{206} \mathrm{~Pb}$ in measured ${ }^{206} \mathrm{~Pb}$, calculated from the ${ }^{204} \mathrm{~Pb}$ signal assuming a present-day Stacey \& Kramers (1975) model terrestrial Pb-isotope composition. 4) In BSE/Cl images, all the analysed zircon domains in sample A2282 are texturally similar and in sample A2362 the xxa refers BSE darker center and xxb the paler outer/rim domains. 


\subsection{Results}

The zircon population from the A2282 Laari granodiorite is very homogeneous consisting mostly of prismatic (length : width $=2-6$ ) and transparent grains. Magmatic zoning is visible especially in the rather dark $\mathrm{Cl}$ images (Fig. 7). Twenty zircon grains were dated using LA-MC-ICPMS (Table 1). On the concordia diagram (Fig. 7a), the U-Pb data plot in a tight cluster defining a $1876 \pm 8 \mathrm{Ma}$ age with a high MSWD of concordance. Therefore the mean $\mathrm{Pb}-\mathrm{Pb}$ age of $1871 \pm 9 \mathrm{Ma}$ (Fig. $7 \mathrm{~b}$ ) is considered the best age estimate for the timing of granodiorite crystallization.
Zircon in the A2362 Arpalahti tonalite is transparent to translucent and stubby. The BSE and CL images usually show BSE-darker/CLpaler center and BSE-paler/CL-darker outer/ rim domains. In the $\mathrm{CL}$ images, mixed type (oscillatory and sector zoning) growth zoning is visible (Fig. 8). Altogether 35 zircon domains from 27 grains were $\mathrm{U}-\mathrm{Pb}$ dated (Table 1). Ages from the center and outer/rim zircon domains are coeval within the error limits. On the concordia diagram (Fig. 9), all the U-Pb data plot in a tight cluster determining an age of $1878 \pm 5 \mathrm{Ma}$ for the tonalite crystallization.

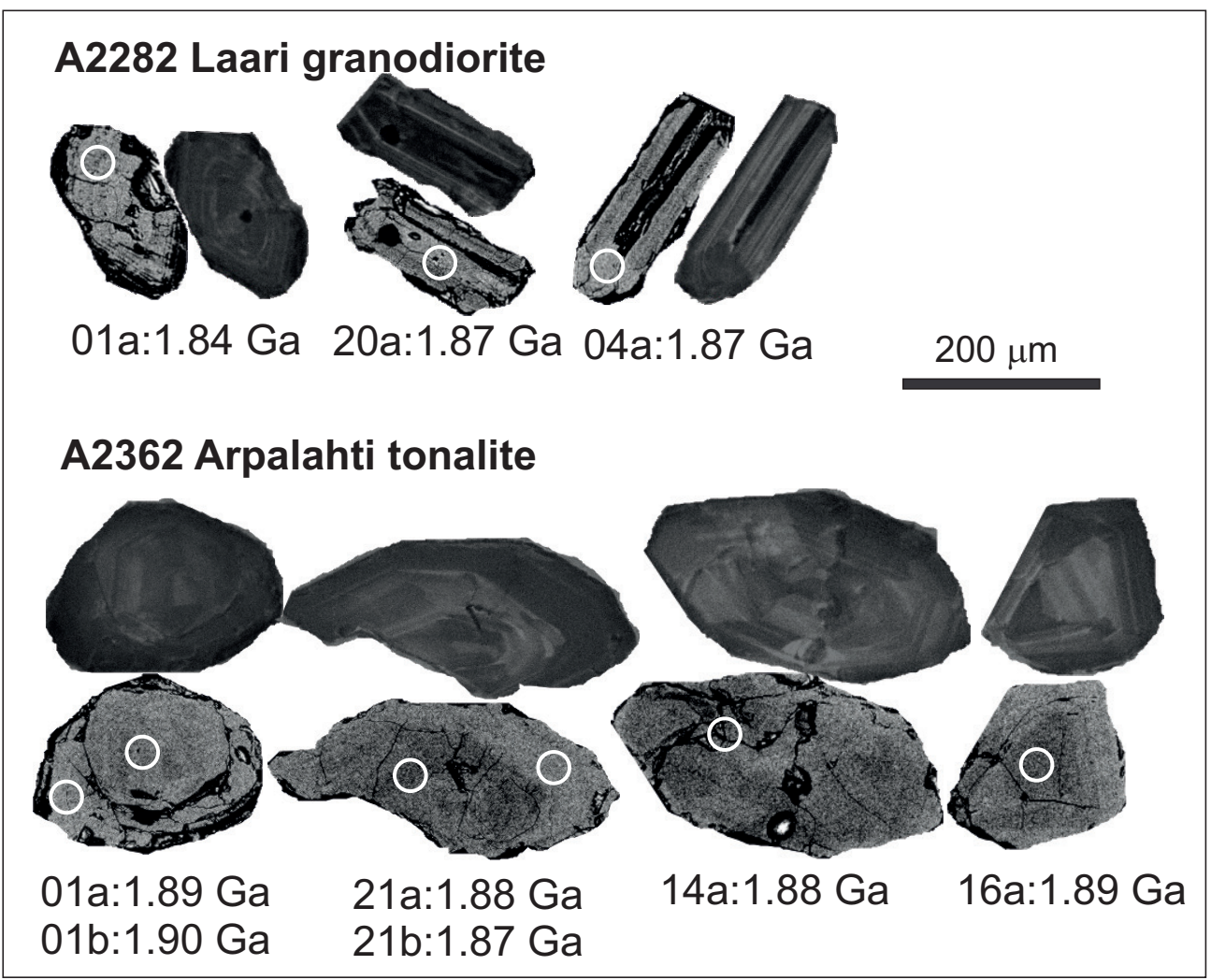

Figure 7. Representative BSE and CL images of U-Pb dated zircon grains from Salittu. The analysis spot sites on the BSE images, corresponding analysis numbers and resulted ${ }^{207} \mathrm{~Pb} /{ }^{206} \mathrm{~Pb}$ ages are indicated. See Table 1. 

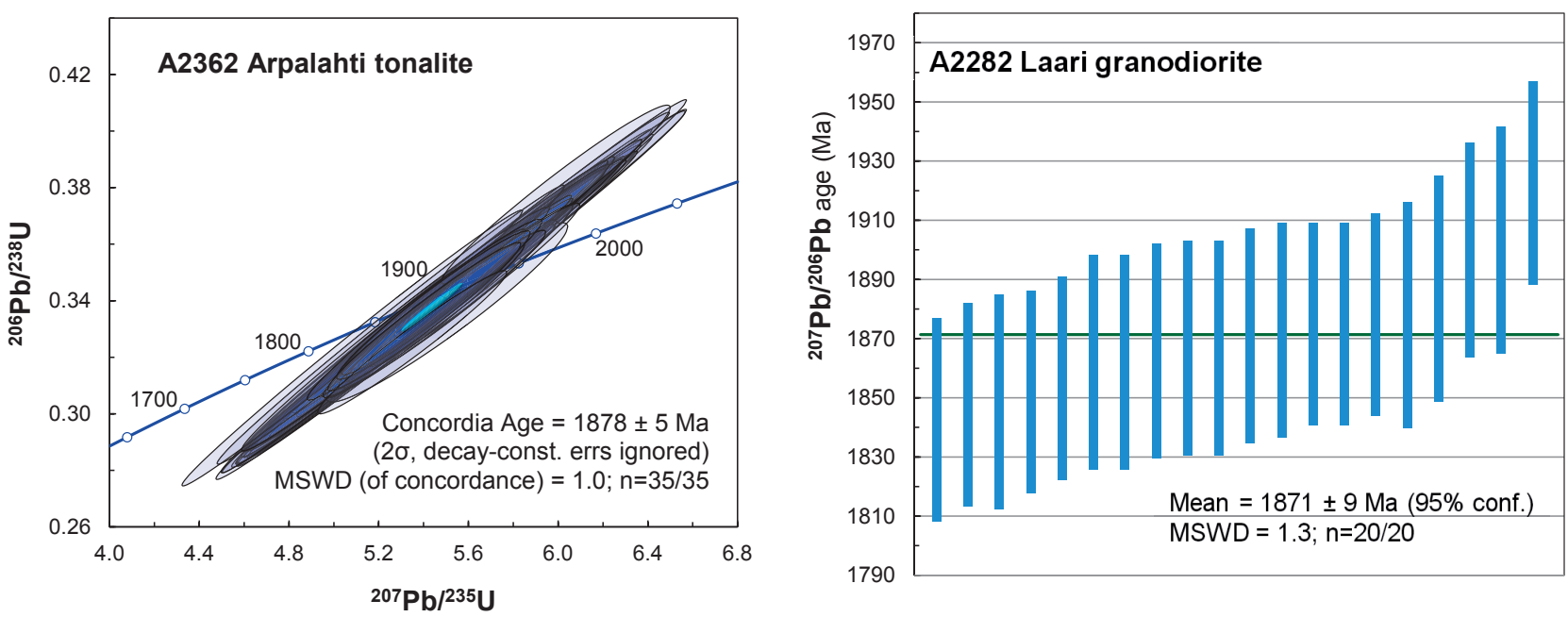

Figure 8. U-Pb age data of the Laari granodiorite. a) Concordia plot. b) ${ }^{207} \mathrm{~Pb} /{ }^{206} \mathrm{~Pb}$ age distribution and mean age.

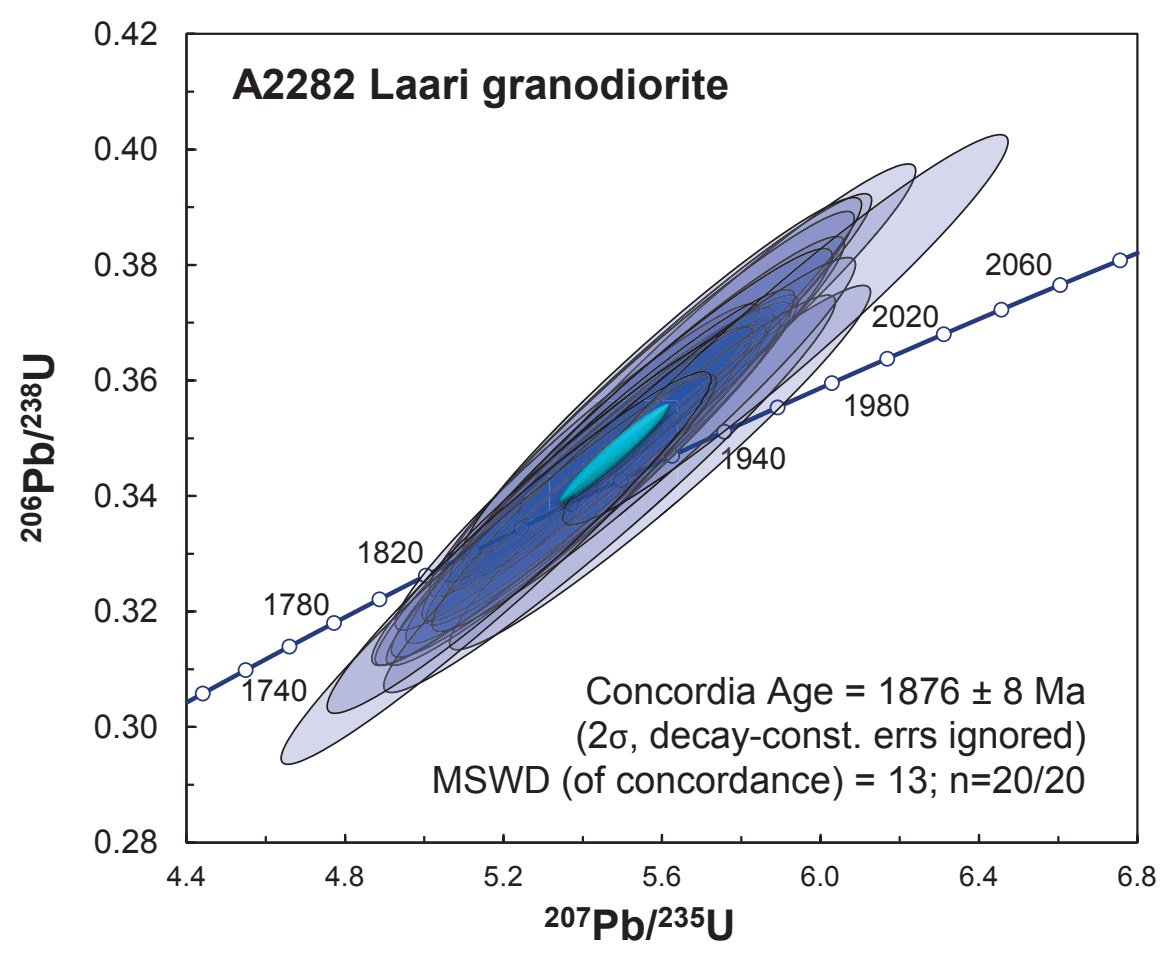

Figure 9. Concordia plot of the Arpalahti tonalite. 
Table 2. Interpretations of deformation events, their styles and orientations of foliations and axial traces in the Orijärvi area.

Ploegsma \& Westra 1990 Skyttä et al. 2006

Early Svecofennian (1.90-1.87 Ga)

D1 (subhorizontal, thrusting)

D2

D1 (subhorizontal,

thrusting)

D2 (upright, ENE-WSW)

Skyttä \& Mänttäri 2008

D1 (subhorizontal, thrusting) D2

Late Svecofennian (1.84-1.79 Ga)

Post-Svecofennian (1.53 Ga)

D3 (upright, N-S)
D3 (upright, E-W)

D4 (upright N-S \& NE, NW shear zones)

$\begin{array}{lll} & \begin{array}{l}\text { D3 (subhorizontal, } \\ \text { extension) }\end{array} & \begin{array}{l}D_{G}-D_{H} \text { (upright, E-W - } \\ \text { horizontal, extension) } \\ \text { D3 (upright, E-W) }\end{array} \\ \text { D4 (upright, ENE-WSW) } & D_{H} \text { (transpression, } \\ \text { upright, NE-SW) } & \\ \text { D4 (upright N-S \& NE, } & \text { D5 (NE, NW shear } & D_{\text {I }} \text { (upright, N-S) } \\ \text { NW shear zones) } & \text { zones) } & \end{array}$

D3 (subhorizontal, xtension zones)
Present study

$\begin{array}{ll}D_{A} \text { (horizontal, } & \text { Dn (subhorizontal, } \\ \text { thrusting) } & \text { thrusting? - upright) } \\ D_{B}-D_{C}-D_{D} \text { (extension - } & \text { Dn+1 (upright) } \\ \text { compression - } & \\ \text { transpression) } & \end{array}$

$D_{\text {A }}$ (horizontal, Dn (subhorizontal, $D_{B}-D_{C}-D_{D}$ (extension - Dn+1 (upright) transpression)

$\mathrm{Dn}+2$ (upright, $\mathrm{N}-\mathrm{S}$ )

\section{Discussion}

\subsection{Structural correlation}

Skyttä et al. (2006) presented a structural sequence for the Orijärvi area with two early Svecofennian and two late Svecofennian deformation events $\mathrm{D}_{1}-\mathrm{D}_{2}$ and $\mathrm{D}_{3}-\mathrm{D}_{4}$, respectively (Table 2 ). In their sequence $S_{1}$ is a weak schistosity subparallel to bedding and possibly associated with thrusting during $\mathrm{D}_{1} ; \mathrm{D}_{2}$ deformation occurred at 1.88-1.87 $\mathrm{Ga} \mathrm{Ma}$ and caused the penetrative $\mathrm{S}_{2}$ foliation with ENE-WSW trend and development of a $\mathrm{D}_{2}$ synform in the northern part of the Orijärvi triangle (Orijärvi sub-area in their terminology, including Sorttila). Subhorizontal $\mathrm{D}_{2}$ structures were refolded into upright folds in the southern part of the Orijärvi triangle during $\mathrm{D}_{3}$ deformation. The Kisko and Jyly shear zones and the different crustal sections in the present erosion surface are the result of E-W contraction during retrograde $\mathrm{D}_{4}$ deformation that continued in brittle regime. Later Skyttä and Mänttäri (2008) refined the deformational sequence over a larger area by adding a crustal extension stage $\mathrm{D}_{3}$ to the beginning of late Svecofennian deformation, at 1835-1825 Ma.
According to Skyttä and Mänttäri (2008), the area east of the Jyly shear zone (including the Salittu area) is dominated by upright $\mathrm{D}_{4}$ structures with ENE-WSW axial planes. $\mathrm{D}_{4}$ deformation started by $\mathrm{N}-\mathrm{S}$ contraction, and counterclockwise rotation of contraction caused strain localization into the subvertical $\mathrm{D}_{5}$ Kisko and Jyly shear zones that were formed after $1820 \mathrm{Ma}$.

In the structural scheme of southern Finland by Pajunen et al. (2008) the western part of the Uusimaa belt is characterized by late Svecofennian dome-and-basin interference structure $\left(D_{\mathrm{G}+\mathrm{H} \pm \mathrm{I}}\right.$, Table 2).

Väisänen and Skyttä (2007) found evidence for contrasting movement senses e.g. in the Jyly shear zone. They proposed that the late Svecofennian oblique-slip reverse faulting (sinistral, east-sideup) caused a positive flower structure in the Jyly shear zone, followed by extensional displacement (east-side-down) in brittle conditions. Väisänen and Skyttä (2007) tentatively suggested such an extension at 1.79-1.77 Ga.

The occurrence of metabasalt inclusions in the metapicrite (Fig. 4b) and the rock type distribution in Figures 5 and 6 imply that the original stratigraphic succession is essentially 
preserved at Salittu and Sorttila: metapicrite overlies metabasalt, and metavolcanic schists and gneisses are below these rocks. The oldest structure at Salittu is the penetrative composite layering $S_{n}$ that can be identified in the gneisses and in the metabasalts. Preservation of the original stratigraphy suggests that the volcanic sequence remained flat-lying during $\mathrm{D}_{\mathrm{n}}$ deformation. However, the style of $\mathrm{D}_{\mathrm{n}}$ is unclear; it may have been thrusting (see Table 2). $\mathrm{D}_{\mathrm{n}}$ anticline at Sorttila may result from upright, rather open $\mathrm{F}_{n}$ folding during a late stage of progressive $\mathrm{D}_{n}$ deformation. $S_{n}$ and $S_{n+1}$ at Sorttila are the same as $S_{1}$ and $S_{2}$ of Skyttä et al. (2006). We interpret that $S_{n}$ and $S_{n+1}$ at Salittu may be correlated with $S_{1}$ and $S_{2}$ as well. The leucosome veins in the gneisses probably developed along $S_{0} / S_{1}$ surfaces during early stages of $\mathrm{D}_{2}$ deformation, and were folded during progressive $\mathrm{D}_{2}$.

We did not find evidence of $\mathrm{D}_{3} / \mathrm{D}_{\mathrm{H}}$ crustal flattening that was suggested to have initiated late Svecofennian deformation (Skyttä and Mänttäri
2008). Neither did we find evidence of largescale, open, upright $\mathrm{D}_{4}$ folding with ENE-WSW trending axial planes which was supposed to characterize the Salittu area; however the tight folding at Laidike, with E-W trending axial planes, is possibly $\mathrm{D}_{4}$ deformation. $\mathrm{F}_{\mathrm{n}+2}$ folding with $\mathrm{N}-\mathrm{S}$ trending axial planes corresponds to $\mathrm{F}_{5}$ and $\mathrm{D}_{\mathrm{I}}$ of Skyttä and Mänttäri (2008) and Pajunen et al. (2008), respectively.

Structural interpretation of the Orijärvi area is shown in Figure 10. The structure at Sorttila was interpreted as $\mathrm{D}_{2}$ synform by Skyttä et al. (2006) but the ovoidal form of exposed metavolcanic rocks suggest the effect of $\mathrm{F}_{5}$ folding. We interpret that the synforms at Laari and Sorttila are the result of two almost orthogonal folding phases, early Svecofennian $\left(\mathrm{D}_{2}\right)$ and late Svecofennian $\left(\mathrm{D}_{5}\right)$. If this interpretation is correct, the Orijärvi triangle was not totally preserved from late Svecofennian deformation (cf. Ploegsma and Westra, 1990).

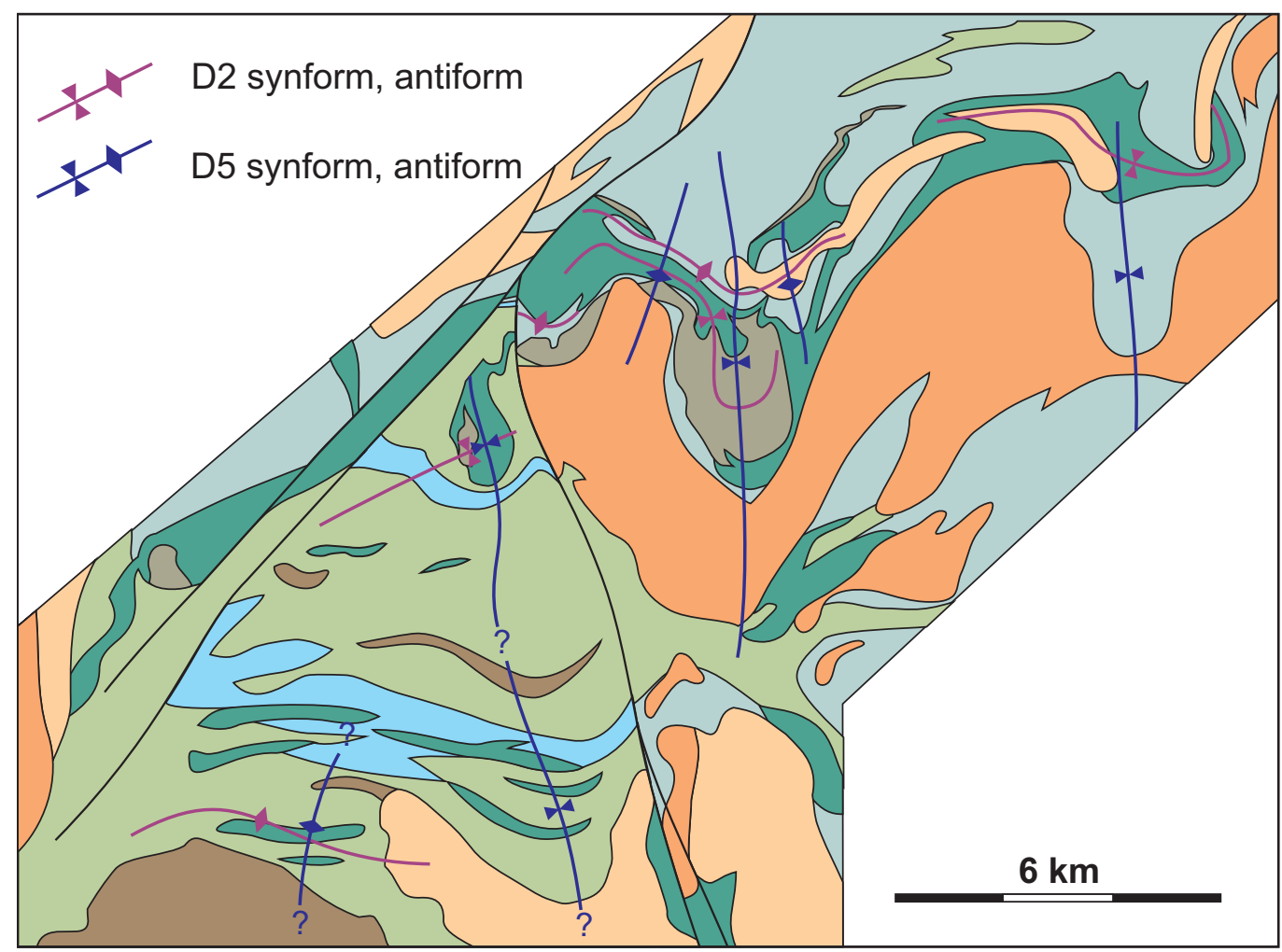

Figure 10. Structural interpretation of the Orijärvi area. Rock types as in Figure 1. 


\subsection{Metamorphism and structural evolution}

As noted by Blom (1988), the $S_{1}-S_{2}$ foliation is in places orthogonal to the metamorphic isogrades, showing that the late Svecofennian thermal pulse overprinted the early Svecofennian structural grain. At Salittu the segregation of melt parallel to $S_{1}$ foliation is interpreted to be an early Svecofennian feature. The implication is that the gneisses represent a deeper section of the crust than rocks in the Orijärvi triangle; the rise in metamorphic grade is not related to the late Svecofennian thermal event.

The Orijärvi area is within the Late Svecofennian Granite-Migmatite zone (Ehlers et al., 1993) but we could not find migmatization at Salittu that was explicitly late Svecofennian. The large granite body around Salittu (Fig. 1) is late Svecofennian because it crosscuts in places early Svecofennian structures (Fig. 3). The small, undeformed granite bodies that occur along faults (Fig. 6) are similar to granites in $\mathrm{D}_{5}$ shear zones (cf. Skyttä and Mänttäri, 2008, Fig. 2). The composite mafic dike at Salittu shows that magmatism during $\mathrm{D}_{5}$ deformation was not only granitic.

Ploegsma and Westra (1990) interpreted that folding $\left(\mathrm{F}_{3}\right)$ with $\mathrm{N}-\mathrm{S}$ trending axial planes governs the large-scale structure at Salittu, and Pajunen et al. (2008) came to a similar conclusion (their $\mathrm{F}_{\mathrm{I}}$ ). These interpetations appear to be valid because the form of the large granite body is curved and the granite contains deformation zones, suggesting large-scale $\mathrm{D}_{5}$ deformation (Fig. 10).

\subsection{Stratigraphy and age correlation}

The oldest ages in the Southern Svecofennia are 1898 $\pm 9 \mathrm{Ma}$ for the Orijärvi granodiorite (Väisänen et al., 2002) and 1895.3 \pm 2.4 Ma for a synplutonic rhyolite at Orijärvi (Väisänen and Mänttäri, 2002). Moreover, Väisänen and Mänttäri (2002) obtained 1878.2 \pm 3.4 Ma age from a dacite from the upper part of the Kisko formation. Subsequently Väisänen and Kirkland (2008) attained $1878 \pm 4$ Ma concordia age from core domains of zircons from a felsic metavolcanic rock of the Toija Formation, and interpreted it to represent the crystallization of the rock. They attempted to date the SFm and although they did not get a direct age they concluded that the formation was deposited between 1878 and $1875 \mathrm{Ma}$.

The Arpalahti tonalite gives the minimum age of for the Salittu metabasalt, and the Laari granodiorite most probably crosscuts the metapicrite. Considering the error limits, the $1874 \pm 8 \mathrm{Ma}$ and $1878 \pm 5 \mathrm{Ma}$ ages for the Laari granodiorite and Arpalahti tonalite, respectively, are the same as the ages obtained from the Kisko and Toija formations. As the dacite from the upper part of the Kisko Formation yielded an $1878.2 \pm 3.4 \mathrm{Ma}$ age, the timing of picritic-basaltic volcanism may be estimated to ca. $1875 \mathrm{Ma}$.

A belt of metapelite (metagreywacke) occurs between the Orijärvi and the Kisko Formations, in the southern limb of the Orijärvi $\mathrm{D}_{2}$ synform (Fig. 1; Väisänen and Mänttäri, 2002; Skyttä et al., 2006). The Vetio site within this belt was studied in detail by Skyttä et al. (2006), Pajunen et al. (2008), and Sayab et al. (2015). Detrital zircons in the metapelite are older $(2.72,2.12-1.93 \mathrm{Ga}$; Claesson et al., 1993) than zircons in the volcanic rocks in the Orijärvi and Kisko Formations. We interpret that the metapelite represents a sedimentary basin that developed after the earlier magmatic event at 1.90 $1.89 \mathrm{Ga}$, and sediments from a large area were mixed in the basin. Since the stratigraphic position of the belt is known within the Orijärvi triangle, we here name it Vetio Formation.

The metasedimentary rocks as well as the overlying intermediate metavolcanic rocks at Sorttila (Fig. 5) were previously considered to be the uppermost part of the Kisko Formation (Väisänen and Mänttäri, 2002). Since the lower part of the Kisko Formation consists solely of metavolcanic rocks, we consider that these rocks form a separate formation within the Orijärvi triangle, here named as Ahdisto Formation. The stratigraphic position of the Ahdisto Formation is correlative to the quartzfeldspar gneisses and biotite gneisses at Salittu. Field evidence suggests that the Toija Formation 


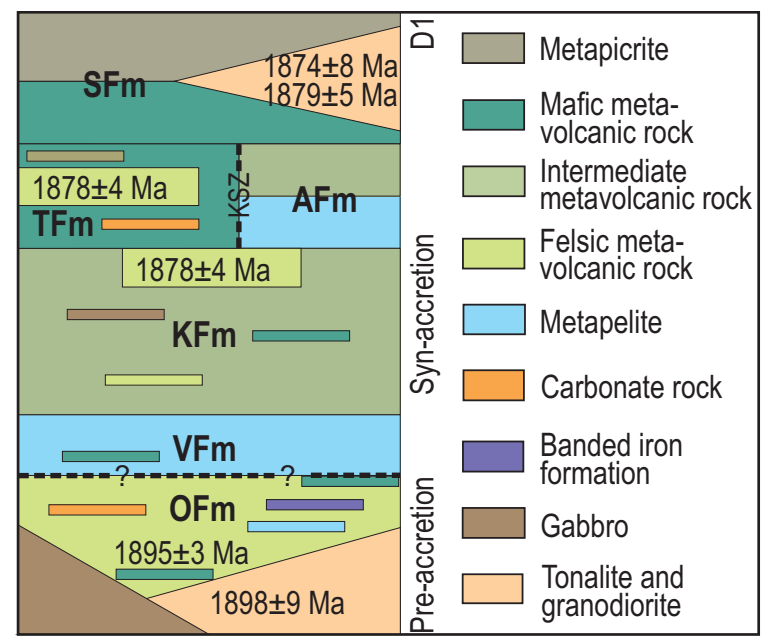

Figure 11. Stratigraphy of the Orijärvi area (not in scale), and related tectonics. Ages from Väisänen and Mänttäri (2002), Väisänen et al. (2002), Väisänen and Kirkland (2008) and this study. Broken line represents a tectonic discordance. OFm = Orijärvi Formation, $\mathrm{VFm}=$ Vetio Formation, KFm = Kisko Formation, TFm = Toija Formation, AFm = Ahdisto Formation, SFm = Salittu Formation, KSZ = Kisko shear zone. See text for explanation.

conformably underlies the Salittu Formation (Väisänen and Mänttäri, 2002). Therefore both the Ahdisto and Toija Formations are stratigraphically below the Salittu Formation but as they are separated by the Kisko shear zone, their mutual position is unknown.

The refined stratigraphy of the Orijärvi area is shown in Figure 11. The Orijärvi Formation is lowermost, with felsic and mafic metavolcanic rocks and interlayers of marble, metapelite and iron formation; stratigraphic interpretation by Latvalahti (1979) differs from that of Colley \& Westra (1987). The synvolcanic granodioritic and gabbroic intrusions are shown. The overlying metasedimentary unit is the new Vetio Formation, with metapelite containing interlayers of mafic metavolcanic rock. The Kisko Formation consists of mafic to felsic metavolcanic rocks. The new Ahdisto Formation between the Kisko and Salittu Formations consists of metasedimentary rocks at the base and intermediate metavolcanic rocks on top. The Toija Formation consists of mafic and felsic metavolcanic rocks, with interlayers of marble and a unit of ultramafic metavolcanic rock in the upper part. Uppermost are the ultramafic-mafic metavolcanic rocks of the SFm, crosscut by the Arpalahti tonalite and the Laari granodiorite.

In the stratigraphic column (Fig. 11) rocks of 1890-1880 Ma age are missing which is somewhat strange considering that this was a period of voluminous crust formation during the Svecofennian orogeny. The ca. $20 \mathrm{Ma}$ age gap between the Orijärvi and Kisko Formations is somewhat loosely constrained because no age data exists from the bottom of the Kisko Formation but at present we take the age gap to be real.

The ca. 1875 Ma picritic-basaltic volcanism of SFm gives the maximum age of $\mathrm{D}_{1}$ deformation. If the presented stratigraphy and structural correlation are correct, deformation of the stratigraphic package overlying the Orijärvi Formation experienced $D_{1}$ deformation at an advanced stage of accretion.

Isotopic evidence suggests an evolved crust in southernmost Finland with an age of $\geq 2.0$ Ma (Lahtinen and Huhma 1997), and therefore $\mathrm{a} \geq 2.0 \mathrm{Ma}$ microcontinental core is assumed to have existed to the south of the Orijärvi area during accretion in the models of Nironen (1997) and Lahtinen et al. (2005). In line with these models we propose the following evolution: the Orijärvi Formation represents magmatism and sedimentation at the margin of this older block that was approaching the subduction zone in the overriding plate; and the overlying volcanic package was formed above the subduction zone when the block started to accrete to another microcontinental block (i.e. accretion of Southern Svecofennia and Central Svecofennia). Because of the proposed duality (pre-accretion vs. accretion sequences) a tectonic discordance is inferred in Figure 11 between the Orijärvi and Vetio Formations. The metapelites of the Vetio Formation represent sediments of the forearc basin and the metavolcanic rocks of the Kisko and Toija Formations are volcanic rocks of the growing magmatic arc. The metavolcanic rocks of the Salittu Formation represent a rifting episode in the magmatic arc (Väisänen and Mänttäri, 2002; Nironen, submitted). 


\section{Conclusions}

The Salittu formation consists of pictitic and basaltic metavolcanic rocks. The original stratigraphy is visible at Salittu although slightly obscured by deformation: metabasalt overlies migmatitic gneisses and metapicrite is on top. The early Svecofennian $\mathrm{D}_{1}$ foliation is visible both in the metavolcanic and metasedimentary rocks. The rocks were folded during the early Svecofennian $\mathrm{D}_{2}$ deformation, and the large synformal structures developed as $\mathrm{D}_{2}-\mathrm{D}_{5}$ interference structures during late Svecofennian $\mathrm{D}_{5}$ deformation. The structural pattern at Salittu is much the same as in the Orijärvi triangle although the metamorphic grade is higher.

The rise in metamorphic grade from the Orijärvi triangle to Salittu is the result of early Svecofennian reverse faulting in the Jyly shear zone, not related to the late Svecofennian thermal event that caused the development of the West Uusimaa Complex.

The new age data, together with earlier published data constrains the Salittu volcanism at ca. $1875 \mathrm{Ma}$. The stratigraphy in the Orijärvi area is refined to consist of the early $(1.90-1.89 \mathrm{Ga})$

\section{References}

Andersen T, Griffin W.L., Jackson S.E., Knudsen T.-L. \& Pearson N.J., 2004. Mid-Proterozoic magmatic arc evolution at the southwest margin of the Baltic Shield. Lithos 73, 289-318. http://dx.doi.org/10.1016/j.lithos.2003.12.011

Belousova E.A., Griffin W.L. \& O’Reilly S.Y., 2006. Zircon crystal morphology, trace element signa- tures and Hf isotope composition as a tool for petrogenetic modeling: examples from Eastern Australian granitoids. Journal of Petrology 47, 329-353. http://dx.doi.org/10.1093/petrology/egi077

Bergman, S., Högdahl, K., Nironen, M., Ogenhall, E., Sjöström, H., Lundqvist, L. \& Lahtinen, R., 2008. Timing of Palaeoproterozoic intra-orogenic sedimentation in the central Fennoscandian Shield: evidence from detrital zircon in metasandstone. Precambrian Research 161, 231-249. http://dx.doi.org/10.1016/j.precamres.2007.08.007

Bleeker, W. \& Westra, L., 1987. The evolution of the Mustio gneiss dome, Svecofennides of SW Finland. Precambrian Research 36, 227-240.

http://dx.doi.org/10.1016/0301-9268(87)90022-2 volcanic unit (Orijärvi Formation), overlain by a mainly sedimentary unit (Vetio Formation), the Kisko Formation, a volcanic-sedimentary unit (Ahdisto Formation), the Toija Formation, and on top the Salittu Formation; these were all emplaced at 1.88-1.87 Ga. We propose a model in which the Orijärvi Formation represents magmatism at the margin of a microcontinent, and the overlying package sedimentation and magmatism above a subduction zone during an initial stage of microcontinental accretion. First identified deformation occurred in an advanced stage of accretion after the emplacement of the volcanic rocks of the Salittu Formation.

\section{Acknowledgements}

The reviews by Taija Torvela and Esa Heilimo improved the manuscript. Thanks to Y. Lahaye for help and keeping the LA-MC-ICPMS working, P. Simelius for rock crushing, M. Saarinen for mineral separation and L. Heikkinen for mount preparation.

Blom, K.A., 1988. Subsolidus migmatization in high-grade metatuffs (Kurkijärvi, southwest Finland). Lithos 21, 263-278. http://dx.doi.org/10.1016/0024-4937(88)90032-1

Claesson, S., Huhma, H., Kinny, P.D. \& Williams, I.S,. 1993. Svecofennian detrital zircon ages - implications for the Precambrian evolution of the Baltic Shield. Precambrian Research 64, 109-130. http://dx.doi.org/10.1016/0301-9268(93)90071-9

Colley, H. \& Westra, L., 1987. The volcano-tectonic setting and mineralization of the early Proterozoic Kemiö-OrijärviLohja belt, SW Finland. In: Pharaoh, T.C., Rickard, D. (eds.) Geochemistry and Mineralization of Proterozoic Volcanic Suites. Geological Society, London, Special Publication 33, 95-107. http://dx.doi.org/10.1144/GSL.SP.1987.033.01.08

Ehlers, C., Lindroos, A. \& Selonen, O., 1993. The late Svecofennian granite-migmatite zone of southern Finland - a belt of transpressive deformation and granite emplacement. Precambrian Research 64, 295-309. http://dx.doi.org/10.1016/0301-9268(93)90083-E 
Eskola, P., 1914. On the petrology of the Orijärvi region in southwestern Finland. Bulletin de la Commission Géologique de Finlande 40, 67-102.

Gorbatschev, R. \& Bogdanova, S., 1993. Frontiers in the Baltic Shield. Precambrian Research 64, 3-21. http://dx.doi.org/10.1016/0301-9268(93)90066-B

Hermansson, T., Stephens, M. B., Corfu, F., Page, L. M., \& Andersson, J., 2008. Migratory tectonic switching, western Svecofennian orogen, central Sweden: Constraints from $\mathrm{U} / \mathrm{Pb}$ zircon and titanite geochronology. Precambrian Research, 161, 250-278.

http://dx.doi.org/10.1016/j.precamres.2007.08.008

Huhma, H., Mänttäri, I., Peltonen, P., Kontinen, A., Halkoaho, T., Hanski, E., Hokkanen, T., Hölttä, P., Juopperi, H., Konnunaho, J., Layahe, Y., Luukkonen. E., Pietikäinen. K., Pulkkinen, A., Sorjonen-Ward, P., Vaasjoki, M. \& Whitehouse, M., 2012. The age of the Archaean greenstone belts in Finland. Geological Survey of Finland, Special Paper 54, 74-175.

Jackson S.E., Pearson N.J., Griffin W.L. \& Belousova E.A., 2004. The application of laser ablation inductively coupled plasma-mass spectrometry to in-situ $\mathrm{U}-\mathrm{Pb}$ zircon geochronology. Chemical Geology 211, 47-69. http://dx.doi.org/10.1016/j.chemgeo.2004.06.017

Lahtinen, R. \& Huhma, H., 1997. Isotopic and geochemical constraints on the evolution of the 1.93-1.79 Ga Svecofennian crust and mantle. Precambrian Research 82, $13-34$.

http://dx.doi.org/10.1016/S0301-9268(96)00062-9

Lahtinen, R., Korja, A. \& Nironen, M., 2005. Paleoproterozoic tectonic evolution. In: Lehtinen, M., Nurmi, P.A., Rämö, O.T. (Eds.) Precambrian Geology of Finland - Key to the Evolution of the Fennoscandian Shield. Elsevier B.V., Amsterdam, 481-532. http://dx.doi.org/10.1016/S0166-2635(05)80012-X

Latvalahti, U., 1979. Cu-Zn-Pb ores in the Aijala-Orijärvi area, southwest Finland. Economic Geology 74, 1035-1059. http://dx.doi.org/10.2113/gsecongeo.74.5.1035

Ludwig, K.R., 2003. Isoplot/Ex 3.00. A geochronological toolkit for Microsoft Excel. Berkeley Geochronology Center. Special publication No. 4 .

Mouri, H., Väisänen, M., Huhma, H. \& Korsman, K., 2005. $\mathrm{Sm}-\mathrm{Nd}$ garnet and $\mathrm{U}-\mathrm{Pb}$ monazite dating of high-grade metamorphism and crustal melting in the West Uusimaa area, southern Finland. GFF 127, 123-128.

http://dx.doi.org/10.1080/11035890501272123

Nironen, M., 1997. The Svecofennian orogen: a tectonic model. Precambrian Research 86, 21-44. http://dx.doi.org/10.1016/S0301-9268(97)00039-9

Nironen, M. The Salittu formation in southwestern Finland II: Arc rifting and picritic-basaltic volcanism in the Paleoproterozoic Svecofennian orogen. Submitted to Bulletin of the Geological Society of Finland.
Pajunen, M., Airo, M-L., Elminen, T., Mänttäri, I., Niemelä, R., Vaarma, M., Wasenius, P. \& Wennerström, M., 2008. Tectonic evolution of the Svecofennian crust in southern Finland. In: Pajunen, M. (Ed.) Tectonic evolution of the Svecofennian crust in Finland - a basis for characterizing bedrock technical properties. Geological Survey of Finland, Special Paper 47, 15-160.

Parras, K., 1958. On the charnockites in the light of a highly metamorphic rock complex in SW Finland. Bulletin de la Commission Géologique de Finlande 181, 1-137.

Ploegsma, M., 1991. A pilot Rb-Sr dating of the Suomusjärvi ultramylonite: evidence for major post-Svecofennian deformation in SW Finland. Bulletin of the Geological Society of Finland 63, 3-13.

Ploegsma, M. \& Westra, L., 1990. The Early Proterozoic Orijärvi triangle (southwest Finland): a key area on the tectonic evolution of the Svecofennides. Precambrian Research 47, 51-69. http://dx.doi.org/10.1016/0301-9268(90)90030-T

Rosa D.R.N., Finch A.A., Andersen T. \& Inverno C.M.C., 2009. $\mathrm{U}-\mathrm{Pb}$ geochronology and $\mathrm{Hf}$ isotope ratios of magmatic zircons from the Iberian pyrite belt. Mineralogy and Petrology 95, 47-69. http://dx.doi.org/10.1007/s00710-008-0022-5

Salli, I., 1955. Geological map of Finland 1:100 000, preQuaternary rocks. Sheet 2023 Suomusjärvi. Geological Survey of Finland.

Sayab, M., Suuronen, J.-P., Hölttä, P., Aerden, D., Lahtinen, R. \& Kallonen, P., 2015. High-resolution X-ray computed microtomography: A holistic approach to metamorphic fabric analyses. Geology 43, 55-58. http://dx.doi.org/10.1130/G36250.1

Schipper, N., 1981. The geology of the Salittu area. Internal report, Department of Geology, Petrology, and Mineralogy, Free University, Amsterdam. 1-44.

Schreurs, J., 1984. The amphibolite-granulite facies transition in West Uusimaa, S.W. Finland. A fluid inclusion study. Journal of Metamorphic Geology 2, 327-341.

http://dx.doi.org/10.1111/j.1525-1314.1984.tb00593.x

Schreurs, J., 1985. Prograde metamorphism of pelites, garnetbiotite thermometry and prograde changes of biotite chemistry in high-grade rocks of West Uusimaa, southwest Finland. Lithos 18,69-80.

http://dx.doi.org/10.1016/0024-4937(85)90011-8

Schreurs, J. \& Westra, L,. 1986. The thermotectonic evolution of a Proterozoic, low pressure, granulite dome, West Uusimaa, SW Finland. Contributions to Mineralogy and Petrology 93, 236-250.

http://dx.doi.org/10.1007/BF00371326

Schreurs, J., van Kooperen, P. \& Westra, L., 1986. Ultramafic metavolcanic rocks of early proterozoic age in WestUusimaa, SW Finland. Neues Jahrbuch für Mineralogie Abhandlungen 155, 185-201. 
Schumacher, J.C. \& Czank, M., 1987. Mineralogy of triple- and double-chain pyriboles from Orijärvi, southwest Finland. American Mineralogist 72, 345-352.

Skyttä, P. \& Mänttäri, I., 2008. Structural setting of late Svecofennian granites and pegmatites in Uusimaa belt, SW Finland: Age constraints and implications for crustal evolution. Precambrian Research 164, 86-109. http://dx.doi.org/10.1016/j.precamres.2008.04.001

Skyttä, P., Väisänen, M. \& Mänttäri, I., 2006. Preservation of Palaeoproterozoic early Svecofennian structures in the Orijärvi area, SW Finland - Evidence for polyphase strain partitioning. Precambrian Research 150, 153-172. http://dx.doi.org/10.1016/j.precamres.2006.07.005

Stacey, J.S. \& Kramers, J.D., 1975. Approximation of terrestrial lead isotope evolution by a two-stage model. Earth and Planetary Science Letters 26, 207-221. http://dx.doi.org/10.1016/0012-821X(75)90088-6

Stephens, M. B., \& Andersson, J., 2015. Migmatization related to mafic underplating and intra- or back-arc spreading above a subduction boundary in a 2.0-1.8 Ga accretionary orogen, Sweden. Precambrian Research, 264, 235-257.

http://dx.doi.org/10.1016/j.precamres.2015.04.019
Tuominen, H.V., 1957. The structure of an Archean area: Orijärvi, Finland. Bulletin de la Commission Géologique de Finlande 177, 1-32.

Väisänen, M. \& Mänttäri, I., 2002. 1.90-1.88 Ga arc and backarc basin in the Orijärvi area, SW Finland. Bulletin of the Geological Society of Finland 74, 185-214.

Väisänen, M. \& Skyttä, P., 2007.Late Svecofennian shear zones in southwestern Finland. GFF 129, 55-64. http://dx.doi.org/10.1080/11035890701291055

Väisänen, M. \& Kirkland, C.I., 2008. U-Th-Pb zircon geochronology on igneous rocks in the Toija and Salittu Formations, Orijärvi area, southwestern Finland: Constraints on the age of volcanism and metamorphism. Bulletin of the Geological Society of Finland 80, 73-87.

Väisänen, M., Mänttäri, I. \& Hölttä, P., 2002. Svecofennian magmatic and metamorphic evolution in southwestern Finland as revealed by U-Pb zircon SIMS geochronology. Precambrian Research 116, 111-127. http://dx.doi.org/10.1016/S0301-9268(02)00019-0

Väisänen, M., Eklund, O., Lahaye, J., O’Brien, H., Fröidö, S., Högdahl, K. \& Lammi, M., 2012. Intra-orogenic Svecofennian magmatism in SW Finland constrained by LA-MC-ICP-MS zircon dating and geochemistry. GFF 134, 99-114.

http://dx.doi.org/10.1080/11035897.2012.680606 